\title{
Measuring Entrepreneurial Orientation in the Social Context
}

\author{
Rafał Kusa
}

\begin{abstract}
A B S T R A C T
Objective: The objective of this paper is to identify differences between measurement of organisational entrepreneurship in for-profit and non-profit context and to propose the measures aligned to non-profit organisations. The main research question is whether the scales designed to measure entrepreneurial orientation can be used in non-profit organisations and under which conditions.
\end{abstract}

Research Design \& Methods: Research methodology is based on review of research tools and measurement scales related to organisational entrepreneurship and comparison of for-profit and non-profit organisations, as well as their characteristics in the context of entrepreneurial orientation.

Findings: Entrepreneurial orientation can be measured in non-profit organisations using existing scales that have been designed for business organisations, however they have to be modified, mostly in the dimension of competitive aggressiveness and autonomy. Additionally, the scale should be enriched with items related to cooperation with other organisations.

Implications \& Recommendations: It is necessary to develop methods and tools that enable the measurement of entrepreneurial orientation in non-profit organisation as well as comparative research on entrepreneurial orientation in for-profit and nonprofit organisations.

Contribution \& Value Added: The originality of this work lies in studying some aspects of entrepreneurial orientation, that apply to the social context. Some suggestions were formulated relating to the utilisation of entrepreneurial orientation scales (originally designed for business enterprises) in non-profit organisations.

\begin{tabular}{ll}
\hline Article type: & conceptual paper \\
Keywords: & social entrepreneurship; entrepreneurial orientation; autonomy; \\
& inter-organisational cooperation \\
JEL codes: & L26, L31
\end{tabular}

\section{Suggested citation:}

Kusa, R. (2016). Measuring Entrepreneurial Orientation in the Social Context. Entrepreneurial Business and Economics Review, 4(3), 117-129, DOI: http://dx.doi.org/10.15678/EBER.2016.040309 


\section{INTRODUCTION}

Entrepreneurship is perceived as one of the sources of success for economies, organisations and human beings. Bhargava notes that "companies which treated entrepreneurship as an integral part of their business strategy succeeded in maintaining top ranks for years" (Bhargava, 2008, p. 31). Entrepreneurship is assigned both to for-profit and nonprofit activities. In the case of the latter type of activity, the concept of social entrepreneurship has been developing over the last few decades.

Non-profit organisations (NPO), including many types of social enterprises that use business activities to provide social needs, play a significant role in modern societies. We have observed an increase in their numbers in many countries as well as an increase in the scale and scope of their activity. Many non-profit organisations face similar problems as for-profit enterprises; for example, limited resources, increasing expectations, or changes in the external environment. Many of them behave in similar ways; for example, they compete for resources, innovate to offer better services, or look for new opportunities to serve new social groups. Accordingly, we can compare them from several points of view. One such view is the level of entrepreneurial activity of the organisations.

The theory of organisational entrepreneurship and its related research methodology have been developing dynamically over the last few decades. However, they mostly focus on business activity. The challenge faced by researchers is to conceptualise and operationalise the organisational entrepreneurship in a social context. One of the concepts that could be applied to this context is entrepreneurial orientation (EO).

The objective of this paper is to investigate whether the scales designed to measure entrepreneurial orientation can be used in non-profit organisations (and under which conditions). Firstly, the concepts of entrepreneurship related to the organisational level are presented. Then, the methodologies dedicated to measuring organisational entrepreneurship are reviewed, with a focus on those scales used to measure the entrepreneurial orientation of organisations. Afterwards, the differences between for-profit and non-profit organisations are analysed (in the context of organisational entrepreneurship). Finally, some modification of the present scales of EO that have been employed by research will be suggested. To achieve the objective, the literature will be reviewed; and based on the results of the review, solutions enabling the measurement of entrepreneurial orientation in the social context will be recommended.

\section{MATERIAL AND METHODS}

The research problem behind this paper is measuring entrepreneurial activity in a nonprofit organisation. The paper is a conceptual one, and its aim is to suggest some related measures adequate to the characteristics of these types of organisations.

To achieve the goal, the following sub-objectives will be achieved: (1) identification of organization-level entrepreneurship concepts; (2) defining specific traits of non-profit activity and their consequences for entrepreneurial activity; (3) recommending measures adequate to the entrepreneurship of non-profit organisations, including verification, if some measures used in for-profit entrepreneurship research could be used. The first and 
second sub-objectives will be pursued by literature studies. Literature from the following fields will be reviewed and analysed:

- the general theory of entrepreneurship,

- organisational entrepreneurship and entrepreneurial orientation,

- social entrepreneurship and non-profit sector.

The relevant materials will be selected mostly from scientific journals focused on the above-mentioned fields. A number of sources will be limited to the most-cited publications; however, some new ones will also be included. Firstly, the materials from each field will be analysed separately, with a focus on issues related to other areas. Then, the propositions resulting from the previous analysis will be suggested and developed. Afterwards, the third sub-objective will be achieved through the critical analysis of present measures and inference based on previous literature studies.

\section{LITERATURE REVIEW}

\section{General Theory of Entrepreneurship}

Entrepreneurship is a multidimensional construct that can be analysed from different perspectives. One of the most-cited contemporary definitions was proposed by Shane and Venkatraman, who define entrepreneurship as a "scholarly examination of how, by whom, and with what effects opportunities to create future goods and services are discovered, evaluated and exploited" (Shane \& Venkatraman, 2000, p. 218). Stevenson, Roberts, and Grousbeck defined entrepreneurship as "a process by which individuals - either on their own or inside organisations - pursue opportunities without regard to the resources they currently control" (Stevenson et al., 1989) quoted in (Stevenson \& Jarillo, 1990, p. 23). Hisrich, Peters and Sheperd (2005) quoted in (Leutner et al., 2014, p. 58) identify entrepreneurship with "behaviours that are related to the creation of value through the exploitation of opportunities in novel and innovative ways". McGrath and MacMillan (2000) quoted in (Ma \& Tan, 2006, p. 714) perceive entrepreneurship as "the relentless pursuit of opportunities as well as resources".

In the above definitions, entrepreneurship is connected with opportunities. Casson (1982) quoted in (Shane \& Venkatraman, 2000, p. 220) defined opportunities as "those situations in which new goods, services, raw materials, and organising methods can be introduced and sold at greater than their cost of production". Opportunity is also defined as a "future situation which is deemed desirable and feasible" (Stevenson \& Jarillo, 1990, p. 23). Shane and Venkatraman (2000, p. 220) acknowledge that opportunities themselves are objective phenomena that are not known to all parties at all times, but the recognition of entrepreneurial opportunities is a subjective process. Kirzner (1997) quoted in (Shane \& Venkatraman, 2000, p. 220) mentions that entrepreneurial opportunities require the discovery of new means-ends relationships, whereas the other for-profit opportunities involve optimisation within existing means-ends frameworks.

Gartner (1989) identifies entrepreneurship with creating organisations. For him, this is an activity that differentiates entrepreneurs from non-entrepreneurs: "entrepreneurs create organisations, while non-entrepreneurs do not" (Gartner, 1989, p. 47).

Entrepreneurship is also perceived as a process that "involves all the functions, activities, and actions associated with the perceiving of opportunities and the creation of 
organisations to pursue them" (Bygrave \& Hofer, 1991, p. 14). Hisrich, Peters and Shepherd (2005) argue that the entrepreneurial process involves the identification and evaluation of opportunity, development of the business plan, determination of the required resources, and management of the resulting enterprise.

Entrepreneurship is also perceived as a set of attitudes, such as the desire to achieve, the passion to create, the yearning for freedom, the drive for independence, and the embodiment of entrepreneurial visions and dreams through tireless hard work, calculated risk-taking, continuous innovation, and undying perseverance (Ma \& Tan, 2006, p. 704).

\section{Organisational Entrepreneurship and Entrepreneurial Orientation}

Entrepreneurship can be treated as a trait of an organisation. It reflects the entrepreneurial behaviours in existing organisations. These "formal or informal activities aimed at creating new businesses in established companies through product and process innovations and market developments" are called corporate entrepreneurship (Zahra, 1991, p. 261) quoted in (Morris \& Kuratko, 2002, p. 31). Corporate entrepreneurship is also perceived as a way of "renewal or innovation within current organization" (Sharma \& Chrisman, 1999, p. 13) quoted in (Morris \& Kuratko, 2002, p. 31). Such a concept shows that the entrepreneurial process does not end when the organisation is founded, but it is continued within that organisation. The entrepreneurial process could be described as a cyclical one, and it could be connected with organisational development. It could be presented on the model of a spiral of the entrepreneurial development of an organisation (Kusa, 2015, p. 705). Kuratko and Audretsch stated that "the major impetus underlying corporate entrepreneurship is to revitalize innovation, creativity, and leadership in corporations. Corporate entrepreneurship may possess the critical components needed for the future productivity of global organizations" (Kuratko \& Audretsch, 2013, p. 332).

Organisations vary in terms of entrepreneurship. Researchers and practitioners strive to measure the level of entrepreneurship in organisations. Morris (1998, p. 18) states that "entrepreneurship occurs in varying degrees and amounts" and suggests the concept of "entrepreneurial intensity". Lumpkin and Dess (1996, p. 137) developed a concept of entrepreneurial orientation (EO). This concept is based on the definition of an entrepreneurial firm, which was proposed by Miller (1983). He stated that "an entrepreneurial firm is one that engages in product-market innovation, undertakes somewhat risky ventures, and is first to come up with 'proactive' innovations, beating competitors to the punch" (Miller, 1983, p. 771). Covin and Slevin (1989, p. 75) have built a scale to measure the EO, which is comprised of three dimensions: risk-taking, innovativeness, and proactiveness, and Lumpkin and Dees (1996, p. 137) augmented it by adding two more dimensions: autonomy and competitive aggressiveness. Some modifications of this scale were proposed. One of them is the scale of Hughes and Morgan, who used 18 items to measure the dimensions of entrepreneurial orientation and 5 items to estimate the business performance of firms at the embryonic stage of development. They have found that uniform effort in all EO dimensions does not generate consistent gains in business performance, and organising activities around proactiveness and, to some extent, innovativeness is essential to securing improved performance for such firms (Hughes \& Morgan, 2007, pp. 657-658). 
Covin and Wales (2012, p. 677) analysed a different measurement approach towards entrepreneurial orientations and stated that "unidimensional versus multidimensional EO measurement models are consistent with fundamentally different conceptualisations of the EO construct". Schillo (2011, p. 24) suggests that entrepreneurial orientation could be useful for practitioners as a source of managerial recommendations. However, entrepreneurial orientation is not an effective concept under all environmental conditions. For example, Frank, Kessler and Fink (2010, p. 194) concluded from their empirical analyses that it "might preferably be pursued in rapidly changing environments that offer new opportunities, and in which the firm has sufficient financial resources at its disposal to take advantage of those opportunities using a portfolio of innovation activities", but it is not advisable using it when "a dynamic environment is combined with low access to financial capital".

\section{Social Entrepreneurship}

Entrepreneurial activities can be observed in non-profit organisations. They are linked with the tendency of becoming 'business-like' of non-profit organisations (Maier, Meyer \& Steinbereithner, 2014, p. 1). Verreynne, Miles and Harris (2013, p. 113) have observed that "these 'profit for purpose' organisations use market transactions to generate social benefits directly (for example by providing employment opportunities for the disabled in sheltered workshops) and/or indirectly (by creating revenues that support social initiatives) for their beneficiaries". Such activities are analysed in the frame of the social entrepreneurship concept, which offers a theoretical basis for such analysis.

Yunus (2011) defines social entrepreneurship as an "initiative of social consequences, taken by an entrepreneur with a social vision, where the initiative may be both noneconomic, associated with a charity or business initiative oriented towards personal profit or without such an option". Mair and Marti (2006, p. 37) perceive social entrepreneurship as "a process involving the innovative use and combination of resources to pursue opportunities to catalyse social change and/or address social needs". They argue that social entrepreneurship can occur in both new organisations and established ones.

Researchers of the European Research Network identify social entrepreneurship with social economy. They define social enterprises as "organisations with an explicit aim to benefit the community, initiated by a group of citizens and in which the material interest of capital investors is subject to limits. Social enterprises also place a high value on their autonomy and on economic risk-taking related to ongoing socio-economic activity" (Defourny \& Nyssens, 2006, p. 5). The model proposed by the European Research Network distinguishes three sets of criteria (three economic and entrepreneurial, three social, and three related to the participatory governance) according to which entities and initiatives are classified as parts of a social economy. The economic criteria comprise a continuous activity, producing goods and/or selling services, a significant level of economic risk, and a minimum amount of paid work. The social criteria include the explicit aim to benefit the community, an initiative launched by a group of citizens or civil society organisations, and a limited profit distribution. Finally, the dimension of participatory governance is described by a high degree of autonomy, a decision-making power not based on capital ownership, and a participatory nature, which involves various parties affected by the activity (Defourny \& Nyssens, 2012, pp. 12-15). 
In the EU's documents, the term 'social enterprise' is used to cover the following types of business (European Commission, 2011, p. 2):

- those for which the social or societal objective of the common good is the reason for the commercial activity, often in the form of a high level of social innovation,

- those where profits are mainly reinvested with a view to achieving this social objective,

- those where the method of organisation or ownership system reflects their mission, using democratic or participatory principles or focusing on social justice.

Because of many approaches to social enterprises as well as different definitions and legal forms dedicated to this kind of activity in different countries, it is not precise to identify social enterprises with non-profit organisations (although many social enterprises could be classified as non-profits). There is an increasing number of publications describing social initiatives (e.g., pioneering social enterprises in Bangladesh (Yunus, 2011) or activities of Ashoka leaders (Bornstein, 2009), as well as reports. One of the examples of statistical research is an examination of social entrepreneurship in 49 countries based on the Global Entrepreneurship Monitor methodology. The results of this research show that in widely defined social entrepreneurship there is a significant part of the population involved: $4.1 \%$ of the population in Belgium, $7.5 \%$ in Finland, 3.1\% in France, 3.3\% in Italy, $5.4 \%$ in Slovenia, and $5.7 \%$ in the United Kingdom (Terjesen, Lepoutre, Justo \& Bosma, 2011). Other statistics show that European social enterprises operate within a wide range of areas, including work integration of disadvantaged groups and social services of general interest such as long-term care for the elderly and for people with disabilities, early education and childcare, employment and training services, social housing, social integration of disadvantaged such as ex-offenders, migrants, drug addicts, etc., and health care and medical services (European Commission, 2014, p. 2).

\section{Applying Entrepreneurial Orientation to Social Entrepreneurship}

Scholars researching non-profit organisations compare them and their management practices with their business counterparts. Austin, Stevenson and Wei-Skillern (2006, pp. 3-4) suggest focussing on the following variables to conduct a comparative analysis:

- market failure, when those needing the services are not able to pay for them, which is perceived as a problem by the commercial entrepreneurs and an opportunity by social ones,

- mission, which is focused on creating social value in the case of social entrepreneurship and on creating profitable operations resulting in private gain in the case of commercial entrepreneurship,

- resource mobilisation, both financial (which are acquired from different sources) and human (staff in non-profit organisations is often not compensated as competitively as in commercial enterprises),

- performance measurement, which relies on relatively tangible and quantifiable measures of performance, such as financial indicators, market share, customer satisfaction, and quality in the case of commercial organisations and a much more challenging measurement of social impact, which will remain a fundamental differentiator, complicating accountability, and stakeholder relations. 
Lumpkin, Moss, Gras, Kato and Amezcua (2013, p. 763) analysed entrepreneurial processes within social contexts and the antecedents and outcomes that make social entrepreneurship unique. They pointed to the presence of a social mission and/or motivation to pursue a social purpose, multiple stakeholders linked to the purpose or mission, and a perspective that opportunity-identification processes may be different when directed toward social problems. They stated that many entrepreneurial processes change very little in the presence of antecedents and outcomes that are related to social context. However, these processes are likely to be challenged by the presence of multiple stakeholders and how autonomy and competitive aggressiveness function in a social context (Lumpkin et al., 2013, p. 780). This is in line with Żur's conclusion that "nonfinancial performance outcomes have not been addressed enough" and suggests spreading the research across different entrepreneurship contexts (such as social and nonprofit) and adjusting relevant scales and measures (Żur, 2015, p. 22).

Morris, Webb and Franklin (2011) relate non-profit organisations directly to entrepreneurial orientation, conceptualised in a three-dimensional scale built by Covin and Slevin (1989). Morris et al. (2011, p. 956) observed that "the meaning of innovativeness, proactiveness, and risk taking are more complex and multifaceted in the non-profit context", and they proposed an alternative conceptualisation, with sub-dimensions emerging for all three dimensions, which are meant to capture the meaning of entrepreneurship and EO more accurately in the non-profit context.

We could find some examples of using EO scales in the non-profit sector. Davis, Marino, Aaron and Tolbert (2011) explored the differences in entrepreneurial orientation by profit status. They surveyed 134 nursing home administrators, and they have found that "there was no significant difference in the EO between non-profits and for-profits, but that non-profits were significantly more likely to engage in environmental scanning activities such as gathering information from trade magazines and suppliers and that they remained abreast of economic and technological trends more than their for-profit counterparts" (Davis et al., 2011, p. 197). Pearce, Fritz and Davis (2009) surveyed 250 religious congregations using a modified Covin and Slevin (1989) EO scale. They observed that entrepreneurial orientation is positively associated with organisational performance (Pearce et al., 2009, p. 219).

\section{DISCUSSION}

The results of the literature review suggest that (1) the theory of entrepreneurship offers different concepts of organisational entrepreneurship, (2) some of these concepts are operationalised, (3) there were some surveys conducted based on these conceptualisations, and (4) some attempts to measure the level of entrepreneurial activity in nonprofit organisations were made. Based on these observations, we can assume that it is possible to measure the level of entrepreneurial activity of non-profit organisations. However, there are still some questions as well as challenges faced by researchers when designing the survey on entrepreneurial orientation in the non-profit sector.

The present experience in measuring organisational entrepreneurship suggests using scales aligned with the concept of entrepreneurial orientation. According to the Covin and Slevin (1989) measure, EO frames innovativeness, proactiveness, and risk-taking. In the Hughes and Morgan (2007) scale, competitive aggressiveness and autonomy is also 
included. The statements related to competitive autonomy, as "In general, our business takes a bold or aggressive approach when competing" or "We try to undo and outmaneuver the competition as best as we can" (Hughes \& Morgan, 2007, p. 659) could be non-relevant to behaviours of non-profit organisations. These organisations tend to focus on their social mission and unmet social needs, and they strive to solve some social problems and maximise social value rather than get a better competitive position and maximise their financial value. On the other hand, NPOs are more willing to cooperate with other organisations working with the same target groups, which is not typical in the case of business enterprises ${ }^{1}$. If we interpret cooperation as a way of pursuing an opportunity to satisfy social needs, we can treat it as a specific dimension of social entrepreneurship. It leads us to the proposition that, in the case of research comparing for-profit and non-profit entrepreneurship, the Hughes and Morgan (2007) scale is more adequate, and it should be expanded to the item or items related to cooperation with other organisations focussed on the same goals. It could be hypothesised that this dimension mostly distinguishes both types of organisations and entrepreneurship (for-profit and nonprofit).

The next attributes that could differentiate both types of organisation are autonomy and independency, which are perceived by Lumpkin and Dees (1996, p. 140) as key components of entrepreneurial orientation. It could be also expected that social entrepreneurs have different attitudes to risk and are led by different motivations to take risk. These differentiating dimensions require special attention during the design of measures and analysis of results.

Some suggested changes in the items in the EO scale are presented in Table 1: original indicators are presented in column $A$, while the suggested indicators aligned with non-profit context are in column B.

Some terminological modifications are required when implementing the scales to social context; e.g., instead of the term "business", the term "organisation" can be used. In the case of tools dedicated to a particular group of organisations, some more changes could be desirable as done by Pearce, Fritz, and Davis (2009), who used the scale of Covin and Slevin (1989) to survey EO in religious congregations - they asked about "new ministries and worship services" instead of "new products and services" (Pearce et al., 2009, p. 219).

Additionally, in the case of comparative research focussed simultaneously on forprofit and non-profit organisations, it is necessary to decide whether one universal measuring tool is to be used or many tools adjusted to particular groups of organisations in parallel. The universal tool could be inadequate for every type of organisation. In the latter case, all of these tools have to be compatible with each other to enable a comparison of results. It could be required to scale the measured dimensions differently in the case of for-profit and non-profit organisations (Morris et al., 2011, p. 966).

\footnotetext{
${ }^{1}$ This does not mean that for-profit enterprises are not able or not willing to cooperate - they do so in many ways, but there are different motivations and expectations behind such activity, as they focus on economic goals (e.g., cooperating with one group of enterprises to compete with another).
} 
Table 1. Examples of indicators of entrepreneurial orientation designed for for-profit and nonprofit organisations

\begin{tabular}{|l|l|}
\hline \multicolumn{1}{|c|}{\begin{tabular}{c}
\multicolumn{1}{c}{ Original content of items } \\
(designed for for-profit organisations)
\end{tabular}} & \multicolumn{1}{c|}{$\begin{array}{c}\text { Modified content of items } \\
\text { (designed for non-profit organisations) }\end{array}$} \\
\hline $\begin{array}{l}\text { In general, the top managers of my firm fa- } \\
\text { vour a strong emphasis on R\&D, technological } \\
\text { leadership, and innovations* }\end{array}$ & $\begin{array}{l}\text { In general, the leaders of my organisation } \\
\text { favour a strong emphasis on scientific analysis } \\
\text { and predictions, pioneering solutions, and } \\
\text { innovations }\end{array}$ \\
\hline $\begin{array}{l}\text { In dealing with its competitors, my firm typi- } \\
\text { cally adopts a very competitive, "undo-the- } \\
\text { competitors" posture* }\end{array}$ & $\begin{array}{l}\text { In dealing with other organisations, my organ- } \\
\text { isation typically focus on the maximisation of } \\
\text { social value, including cooperation with other } \\
\text { organisations }\end{array}$ \\
\hline $\begin{array}{l}\text { In general, the top managers of my firm have } \\
\text { a strong proclivity for high-risk projects (with } \\
\text { chances of very high returns)* }\end{array}$ & $\begin{array}{l}\text { In general, the leaders and top managers of } \\
\text { my organisation have a strong proclivity for } \\
\text { high-risk projects (with chances of solving the } \\
\text { most difficult social problems) }\end{array}$ \\
\hline $\begin{array}{l}\text { We always try to take the initiative in every } \\
\text { situation (e.g., against competitors, in projects } \\
\text { when working with others)** }\end{array}$ & $\begin{array}{l}\text { We always try to take the initiative in every } \\
\text { situation (e.g., against groups of opponents or } \\
\text { sceptics, in projects when working with oth- } \\
\text { ers) }\end{array}$ \\
\hline $\begin{array}{l}\text { In general, our business takes a bold or ag- } \\
\text { gressive approach when competing** }\end{array}$ & $\begin{array}{l}\text { In general, our organisation takes a bold or } \\
\text { aggressive approach in the face of total inabil- } \\
\text { ity }\end{array}$ \\
\hline $\begin{array}{l}\text { We try to undo and out-maneuver the com- } \\
\text { petition as best as we can** }\end{array}$ & $\begin{array}{l}\text { We try to convince other organisation to } \\
\text { cooperate with us or to support our aims as } \\
\text { best as we can }\end{array}$ \\
\hline
\end{tabular}

$*$ items from the Covin and Slevin EO scale

** items from the Hughes and Morgan EO scale

Source: own elaboration based on (Hughes \& Morgan, 2007, p. 659; Covin \& Wales, 2012, p. 692).

\section{CONCLUSIONS}

Measuring entrepreneurial activity in non-profit organisations is one of the challenges faced by researchers and practitioners. Literature studies show that there are some methodologies that enable the measurement of such activities in business organisations. The entrepreneurial orientation scales (designed originally for for-profit organisations) can be used in non-profit organisations. However, they require some modification. These modifications refer especially to those dimensions that differentiate both types of organisation. According to the results of the literature study, these areas include relations with other organisations as well as the autonomy of the employees and members. Taking into account the findings above, modifications of some items of the EO scales were suggested in the paper.

It should be noted that, as entrepreneurship is a multidimensional phenomenon that occurs in many types of activities, the suggested modifications could be irrelevant to each organisation. Moreover, the EO scales simplify the phenomenon of entrepreneurship, which may result in skipping or not fully reflecting some attributes of the entrepreneurship. Relying on experiences from business organisations may lead to omitting some 
aspects of entrepreneurship that are important within non-profit organisations but not relevant to business organisations (and not reflected in the original scales). To minimise these limits, it is necessary to explore the specific characteristics of the surveyed organisations and their environment. Creating new scales dedicated solely for non-profit organisations emerges as an alternative solution. However, such a new scale needs to be statistically tested, while the existing ones have already been verified. The next limitation is connected with the geographical context. The analysed literature reflects the characteristics of entrepreneurial practice in the non-profit sector in the European Union and the United States. The findings and recommendations might not be applicable to non-profit organisations operating in other regions. This limitation is connected partly with the methods applied in the paper, and it could be recommended to extend the scope of future research to other areas as well as include other research methods to verify the propositions.

The literature study and (especially) the published results of existing research suggest that it is desirable to support entrepreneurial behaviours in non-profit organisations. Practical prompts for practitioners are needed; for example, which solutions from for-profit organisations could be implemented in non-profit ones (and vice-versa) or how can entrepreneurship in non-profit organisations be supported?

Parallel to developing practical knowledge, the theoretical base should be expanded. To understand the nature of entrepreneurship as a universal phenomenon existing in different kinds of activities, it is recommended to conduct comparative studies covering both social and business organisations. One of the questions to be answered is: In which dimensions are social and business entrepreneurship similar, and in which ones are they different? To understand the nature of social entrepreneurship, it is important to compare entrepreneurial behaviours in social enterprises and other types of non-profit organisation (e.g., charities, associations) and to explore which organisational or legal forms of non-profit organisations are more eligible for using business activities to strengthen the achievement of their social goals. Comparing entrepreneurship in nonprofit and for-profit organisations, or traditional non-profits with social enterprises, requires the development of research methodology, including the design of a questionnaire or methods of collecting data.

Taking into account the role of the non-profit sector, researching entrepreneurial orientation in a social context is reasonable objective, as it could support the future development of non-profit organisations and (furthermore) their effectiveness in solving social problems.

\section{REFERENCES}

Austin, J., Stevenson, H., \& Wei-Skillern, J. (2006). Social and commercial entrepreneurship: Same, different, or both?. Entrepreneurship Theory and Practice, 30(1), 1-22. doi: 10.1111/j.15406520.2006.00107.x

Bhargava, S. (2008). Entrepreneurial Management: Emergence of a New Field. In S. Bhargava (Ed.), Entrepreneurial Management (pp. 1-41). Los Angeles: SAGE Publications.

Bornstein, D. (2009). Jak zmienić świat. Przedsiębiorcy społeczni - wizjonerzy naszych czasów. Gdańsk: AnWero Wydawnictwo. 
Bygrave, W.D., \& Hofer, C.W. (1991). Theorizing about entrepreneurship. Entrepreneurship Theory and Practice, 16(2), 13-22.

Casson, M. (1982). The entrepreneur. Totowa, NJ: Barnes \& Noble Books.

Covin, J.G., \& Slevin, D.P. (1989). Strategic management of small firms in hostile and benign environments. Strategic Management Journal, 10, 75-87. doi: 10.1002/smj.4250100107

Covin, J.G., \& Wales, W.J. (2012). The Measurement of Entrepreneurial Orientation. Entrepreneurship Theory and Practice, 36(4), 677-702. doi: 10.1111/j.1540-6520.2010.00432.x

Davis, J.A., Marino, L.D., Aaron, J.R., \& Tolbert, C.L. (2011). An Examination of Entrepreneurial Orientation, Environmental Scanning, and Market Strategies of Nonprofit and For-Profit Nursing Home Administrators. Nonprofit and Voluntary Sector Quarterly, 40, 197-211. doi: 10.1111/10.1177/0899764009351112

Defourny, J., \& Nyssens, M. (2006). Defining social enterprise. In M. Nyssens (Ed.), Social Enterprise. At the crossroads of market, public policies and civil society (pp. 3-26). London and New York: Routledge.

Defourny, J., \& Nyssens, M. (2012). The EMES approach of social enterprise in a comparative perspective. EMES Working Papers Series, 12(3). Retrieved on April 30, 2016 from http://www.emes.net

European Commission (2011). Social Business Initiative: Creating a favorable climate for social enterprises, key stakeholders in the social economy and innovation. COM (2011) 682 final, Brussels.

European Commission. (2014). A map of social enterprises and their ecosystems in Europe. Executive Summary. London: ICF Consulting Service.

Frank, H., Kessler, A., \& Fink, M. (2010). Entrepreneurial Orientation and Business Performance - a Replication Study. Schmalenbach Business Review, 62, 175-198.

Gartner, W.B. (1989). „Who is an entrepreneur?” Is the wrong question. Entrepreneurship Theory and Practice, Summer, 47-67.

Hisrich, R.D., Peters, M.P., \& Shepherd, D.A. (2005). Entrepreneurship (6th Edition). New York, USA: McGraw-Hill Irwin.

Hughes, M., \& Morgan, R.E. (2007). Deconstructing the relationship between entrepreneurial orientation and business performance at the embryonic stage of firm growth. Industrial Marketing Management, 36,651-661. doi: 10.1016/j.indmarman.2006.04.003

Kirzner, I. (1997). Entrepreneurial discovery and the competitive market process: An Austrian approach. Journal of Economic Literature, 35, 60-85.

Kuratko, D.F., \& Audretsch, D.B. (2013). Clarifying the domains of corporate entrepreneurship. International Entrepreneurship Management Journal, 9, 323-335. doi: 10.1007/s11365-0130257-4

Kusa, R. (2015). Rozwój organizacji i proces przedsiębiorczości. Marketing i Rynek, 5, 696-707.

Leutner, F., Ahmetoglu, G., Akhtar, R., \& Chamorro-Premuzic, T., (2014). The relationship between the entrepreneurial personality and the Big Five personality traits. Personality and Individual Differences, 63, 58-63. doi: 10.1016/j.paid.2014.01.042

Lumpkin, G.T., \& Dess, G.G. (1996). Clarifying the entrepreneurial orientation construct and linking it to performance. Academy of Management Review, 21, 135-172.

Lumpkin, G.T., Moss, T.W., Gras, D.M., Kato, S., \& Amezcua, A.S. (2013). Entrepreneurial processes in social contexts: how are they different, if at all? Small Business Economics, 40, 761-783. doi:10.1007/s11187-011-9399-3 
Ma, H., \& Tan J., (2006). Key components and implications of entrepreneurship: A 4-P framework. Journal of Business Venturing, 21, 704-725. doi: 10.2139/ssrn.1552136

Mair, J., \& Marti, I. (2006). Social entrepreneurship research: A source of explanation, prediction, and delight. Journal of World Business, 41, 36-44.

Maier, F., Meyer, M., \& Steinbereithner, M. (2014). Nonprofit Organizations Becoming BusinessLike: A Systematic Review. Nonprofit and Voluntary Sector Quarterly, 1-23. doi:10.1177/ 0899764014561796

McGrath, R.G., \& MacMillan, I.C. (2000). The Entrepreneurial Mindset: Strategies for Continuosly Creating Opportunity in the Age of Uncertainty. Boston, MA: Harvard Business School Press.

Miller, D. (1983). The correlates of entrepreneurship in three types of firms. Management Science, 29(7), 770-791.

Morris, M.H. (1998). Entrepreneurial Intensity: sustainable advantages for individuals, organizations and societies. Westport CT: Quorum Books.

Morris, M.H., \& Kuratko D.F. (2002). Corporate Entrepreneurship. Entrepreneurial Development within Organizations. Thomson South-Western.

Morris, M.H., Webb, J.W., \& Franklin, R.J. (2011). Understanding the Manifestation of Entrepreneurial Orientation in the Nonprofit Context. Entrepreneurship Theory and Practice, 35(5), 947-971. doi: 10.1111/j.1540-6520.2011.00453.x

Pearce, J.A.II, Fritz, D.A., \& Davis, P.S. (2009). Entrepreneurial Orientation and the Performance of Religious Congregations as Predicted by Rational Choice Theory. Entrepreneurship Theory and Practice, 34(1), 219-248. doi: 10.1111/j.1540-6520.2009.00315.x

Schillo, S. (2011). Entrepreneurial Orientation and Company Performance: Can the Academic Literature Guide Managers? Technology Innovation Management Review, November, 20-25.

Shane, S., \& Venkatraman, S. (2000). The promise of entrepreneurship as a field of research. Academy of Management Review, 25, 217-226.

Sharma, P., \& Chrisman, J.J. (1999). Toward a Reconciliation of the Definitional Issues in the Field of Corporate Entrepreneurship. Entrepreneurship Theory and Practice, 23(3), 11-28.

Stevenson, H.H., Roberts M.J., \& Grousbeck H.I. (1989). New Business Ventures and the Entrepreneur. Homewood, IL: Irwin.

Stevenson, H.H., \& Jarillo J.C. (1990). A Paradigm of Entrepreneurship: Entrepreneurial Management. Strategic Management Journal, 11(4), 17-27.

Terjesen, S., Lepoutre, J., Justo, R., \& Bosma, N. (2011). Global Entrepreneurship Monitor Report on Social Entrepreneurship. GEM: Global Entrepreneurship Monitor. Global Entrepreneurship Research Association.

Verreynne, M.L., Miles, M.P., \& Harris, C. (2013). A short note on entrepreneurship as method: a social enterprise perspective. International Entrepreneurship Management Journal, 9, 113128. doi: 10.1007/s11365-012-0239-y

Yunus, M. (2011). Przedsiębiorstwo społeczne. Kapitalizm dla ludzi. Warszawa: ConCorda.

Zahra, S.A. (1991). Predictors and Financial Outcomes of Corporate Entrepreneurship: An Exploratory Study. Journal of Business Venturing, 6(4), 259-286. doi: 10.1016/0883-9026(91)90019-A

Żur, A. (2013). Entrepreneurial Orientation and Firm Performance - Challenges for Research and Practice. Entrepreneurial Business and Economics Review, 1(2), 7-27. doi: 10.15678/ EBER.2013.010202 


\section{Author}

\section{Rafał Kusa}

Assistant Professor in the Faculty of Management of the AGH University of Science and Technology in Krakow (Poland). PhD in Economics by the Faculty of Economics and International Relations of the Cracow University of Economics (Poland); Degree in Management and Marketing by the Faculty of Management of the Cracow University of Economics (Poland).

Correspondence to: Dr Rafał Kusa; AGH University of Science and Technology; Faculty of Management; ul. Gramatyka 10, 30-067 Kraków, Poland; e-mail: rkusa@zarz.agh.edu.pl

\section{Acknowledgements and Financial Disclosure}

The article came into being within the project no. 11/11.200.272 entitled 'Zarządzanie przedsiębiorstwami w warunkach gospodarki globalnej' financed by MNiSzW conducted by Faculty of Management of AGH University of Science and Technology in Krakow in the years 2014-2016.

Author would like to thank the anonymous referees for their useful comments, which allowed to increase the value of this article.

\section{Copyright and License}

This article is published under the terms of the Creative Commons Attribution - NonCommercial - NoDerivs (CC BY-NC-ND 3.0) License http://creativecommons.org/licenses/by-nc-nd/3.0/ 
